九州大学学術情報リポジトリ

Kyushu University Institutional Repository

\title{
Characterization of the Classical Complement Pathway of Rainbow Trout
}

Nakao, Miki

Laboratory of Fisheries Chemistry, Faculty of Agriculture, Kyushu University

Yano, Tomoki

Laboratory of Fisheries Chemistry, Faculty of Agriculture, Kyushu University

https://doi.org/10.5109/23917

出版情報：九州大学大学院農学研究院紀要. 33 (1/2)，pp.61-65，1988-10. Kyushu University バージョン：

権利関係 : 


\title{
Characterization of the Classical Complement $P$ athway of $R$ ainbow Trout
}

\author{
M iki N akao and Tomoki $\mathrm{Yano}$ \\ Laboratory of Fisheries Chemistry, Faculty of Agriculture, \\ Kyushu University 46-04, Fukuoka 812, Japan. \\ (Received May 13, 1988)
}

\begin{abstract}
Characteristics of the classical complement pathway (CCP) of rainbow trout Salmo gairdneri was examined using sheep red blood cells sensitized with porgy Pagrus major antibody which is compatible with rainbow trout complement. The rainbow trout CCP showed the highest activity when the reaction was performed at $20-25^{\circ} \mathrm{C}$ and around $\mathrm{pH} 7.5$, and the hemolysis reached a plateau in about $120 \mathrm{~min}$. It was found that a considerable hemolysis which is attributable to the alternative complement pathway (ACP) of rainbow trout took place in the presence of $10 \mathrm{mM} \mathrm{Mg}^{2+}$. The hemolysis caused by the ACP, however, was less than $10 \%$ of the total hemolysis when the hemolytic reaction was performed in the presence of $1 \mathrm{mMCa}^{2+}$ and $1 \mathrm{mMMg}^{2+}$.
\end{abstract}

\section{INTRODUCTION}

In previous studies (Yano et al., 1984 ; Matsuyama et $a l ., 1985$; Yano et al., 1988), we investigated the optimum conditions for the assay of the classical complement pathway (CCP) activity of carp Cyprinus carpio, porgy Pagrus major and tilapia Tilapia nilotica by use of sheep red blood cells (SRBC) sensitized with the antibodies of these fishes.

In the present work, we examined the optimum conditions for the assay of the CCP activity of rainbow trout Salmo gairdneri using SRBC sensitized with porgy antibody which is compatible with rainbow trout complement.

\section{MATERIALS AND METHODS}

\section{R eagents}

The sources of reagents were as follows : EDTA (ethylenediaminetetraacetic acid) and barbital sodium, Wako Pure Chemical Industries Co., Osaka ; Amberlite IRC50, Organo Co., Tokyo ; sheep blood in Alsever's solution, Japan Bio-Supply Center, Tokyo.

The buffers used in the experiment and their abbreviations were as follows : $\mathrm{GVB}^{2+}$, veronal-buffered saline $(\mathrm{pH} 7.4)$ containing $0.1 \%$ gelatin, $0.15 \mathrm{mM} \mathrm{CaCl}_{2}$ and $0.5 \mathrm{mM} \mathrm{MgCl}_{2}$;EDTA.GVB, veronal-buffered saline ( $\mathrm{pH} 7.4$ ) containing $0.1 \%$ gelatin and $10 \mathrm{mM}$ EDTA ; GVB(f), veronal-buffered saline ( $\mathrm{pH} 7.4$ ), free of divalent cations, containing $0.1 \%$ gelatin. GVB(f) was made by passing $200 \mathrm{ml}$ of veronal-buffered saline containing $0.1 \%$ gelatin through an Amberlite IRC-50 column $(5 \mathrm{ml})$ equilibrated with $0.15 \mathrm{M} \mathrm{NaCl}$. 


\section{Rainbow trout serum}

Blood was collected from the caudal vessel of rainbow trout, weighing about 250 $\mathrm{g}$, clotted at room temperature for $30 \mathrm{~min}$ and then cooled at $0^{\circ} \mathrm{C}$ for $1 \mathrm{~h}$. After centrifugation, the serum was frozen in liquid nitrogen and stored at $-80^{\circ} \mathrm{C}$.

\section{Preparation of sensitized sheep red blood cells (EA)}

EA (sheep red blood cells sensitized with porgy antibody) were prepared as described in the previous paper (Matsuyama et al., 1985) and suspended in $\mathrm{GVB}^{2+}$ at a concentration of $5 \times 10^{8} \mathrm{cells} / \mathrm{ml}$. This EA suspension was stored at $4{ }^{\circ} \mathrm{C}$ and used within one week.

\section{Removal of divalent cations from rainbow trout serum}

Rainbow trout serum $(0.2 \mathrm{ml})$ was applied to an Amberlite IRC-50 column $(3 \mathrm{ml})$ equilibrated with $\mathrm{GVB}(\mathrm{f})$ and eluted with the same buffer. The first eluate $(0.5 \mathrm{ml})$ was discarded, and the next eluate $(4 \mathrm{ml})$ was used as serum(f).

\section{RESULTS}

Effect of incubation temperature on the activity of the rainbow trout $\mathrm{CCP}$

The reaction mixture composed of $0.10 \mathrm{ml}$ of EA suspension $\left(5 \times 10^{8}\right.$ cells $\left./ \mathrm{ml}\right), 0.25$ $\mathrm{ml}$ of diluted rainbow trout serum $(1 / 60)$ and $0.40 \mathrm{ml}$ of $\mathrm{GVB}^{2+}$ was incubated at various temperatures ranging from 0 to $37^{\circ} \mathrm{C}$ for $30 \mathrm{~min}$. The reaction was stopped by adding $0.75 \mathrm{ml}$ of EDTA $\cdot \mathrm{GVB}$ and, after centrifugation, percent hemolysis was calculated from the absorbance at $541 \mathrm{~nm}$ of the supernatant. Fig. 1 shows that rainbow trout complement was most active at $20-25^{\circ} \mathrm{C}$.

\section{Effect of $\mathbf{p H}$ on the activity of the rainbow trout $\mathbf{C C P}$}

The $\mathrm{pH}$ of $\mathrm{GVB}^{2+}$ was readjusted to $6.0,6.5,7.0,7.5,8.0,8.5$ and 9.5 with $1 \mathrm{~N} \mathrm{HCl}$ or $1 \mathrm{~N} \mathrm{NaOH}$, and the hemolytic reactions were carried out at $20^{\circ} \mathrm{C}$ for $40 \mathrm{~min}$. After

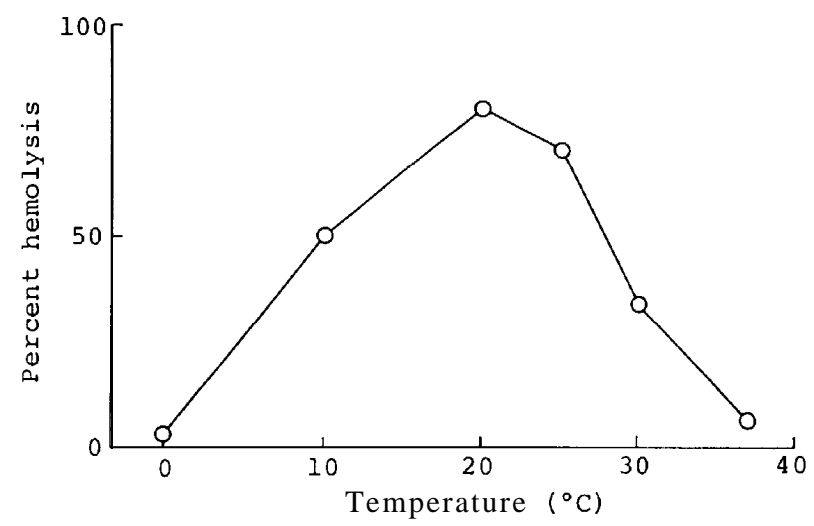

Fig. 1. Effect of incubation temperature on the classical complement pathway activity of rainbow trout. The hemolytic reaction was performed at 0 to $37^{\circ} \mathrm{C}$ for $30 \mathrm{~min}$ at pH 7.4. 


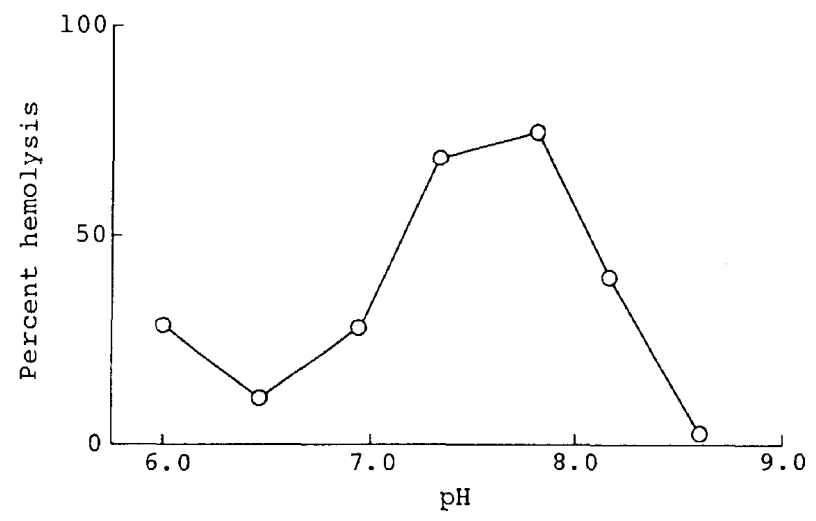

Fig. 2. Effect of $\mathrm{pH}$ on the classical complement pathway activity of rainbow trout. The hemolytic reaction was performed at $20^{\circ} \mathrm{C}$ for $40 \mathrm{~min}$.

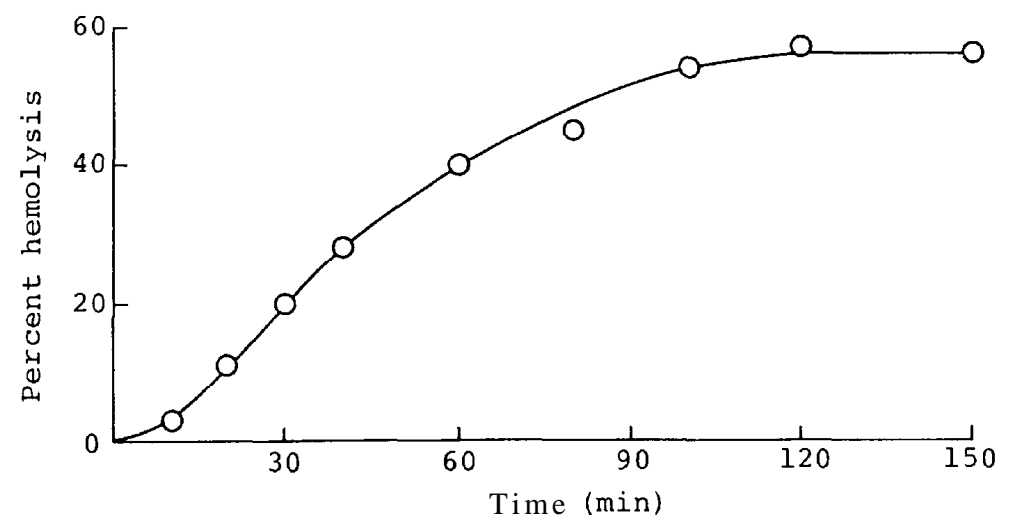

Fig. 3. Time course of hemolysis in the reaction of rainbow trout complement with sensitized SRBC. The hemolytic reaction was performed at $20^{\circ} \mathrm{C}$ for $150 \mathrm{~min}$ at $\mathrm{pH} 7.5$.

addition of $0.75 \mathrm{ml}$ of EDTA $\cdot \mathrm{GVB}$, each mixture was centrifuged and the percent hemolysis was calculated. As shown in Fig. 2, the highest activity was observed around $\mathrm{pH} 7.5$.

\section{Time course of hemolysis}

The reaction mixture $(7.5 \mathrm{ml})$ was incubated at $20^{\circ} \mathrm{C}$ for $150 \mathrm{~min}$ at $\mathrm{pH} 7.5$. At timed intervals, an aliquot $(0.75 \mathrm{ml})$ of the reaction mixture was withdrawn and mixed with $0.75 \mathrm{ml}$ of EDTA-GVB, and percent hemolysis at each time point was calculated (Fig. 3). Hemolysis took place after a lag-time of about $10 \mathrm{~min}$ and, proceeding rather slowly, reached a plateau in about $120 \mathrm{~min}$.

\section{CCP}

E ffect of concentrations of $\mathrm{Ca}^{2+}$ and $\mathrm{Mg}^{2+}$ on the activity of the rainbow trout

To a reaction mixture composed of $0.25 \mathrm{ml}$ of serum(f), $0.10 \mathrm{ml}$ of EA suspension 

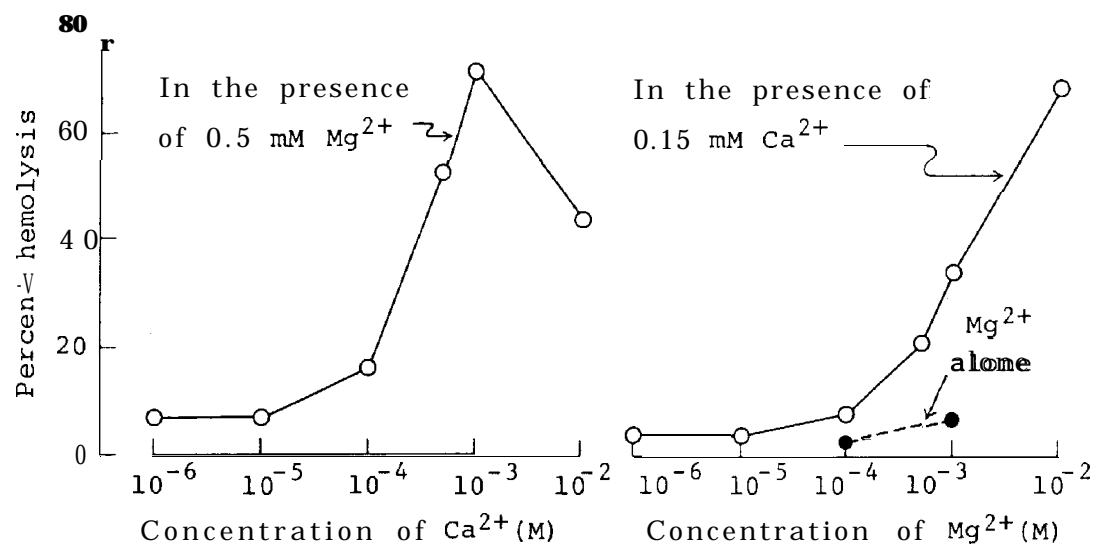

Fig. 4. Effect of concentrations of $\mathrm{Ca}^{2+}$ and $\mathrm{Mg}^{2+}$ on the classical complement pathway activity of rainbow trout. The hemolytic reaction was performed at $20^{\circ} \mathrm{C}$ for $40 \mathrm{~min}$.

( $5 \times 10^{8}$ cells $/ \mathrm{ml} \mathrm{GVB} \mathrm{(f))} \mathrm{and} 0.40 \mathrm{ml}$ of GVB (f) were added $5 \mu \mathrm{lof} \mathrm{CaCl}_{2}$ solution and $5 \mu \mathrm{lof} \mathrm{MgCl}_{2}$ solution. The mixture was incubated at $20^{\circ} \mathrm{C}$ for $40 \mathrm{~min}$ at $\mathrm{pH} \mathrm{7.5}$. The concentrations of $\mathrm{Ca}^{2+}$ was altered from $10^{-6}$ to $10^{-2} \mathrm{M}$ in the presence of $0.5 \mathrm{mM} \mathrm{Mg}^{2+}$, and the concentration of $\mathrm{Mg}^{2+}$ was altered from $10^{-6}$ to $10^{-2} \mathrm{M}$ in the presence of 0.15 $\mathrm{mM} \mathrm{Ca}^{2+}$. As a result, the highest activity was observed at $10^{-3} \mathrm{M} \mathrm{Ca}^{2+}$ and at $10^{-2}$ $\mathrm{M} \mathrm{Mg}^{2+}$ (Fig. 4). Slight hemolysis was observed when the reaction mixture was incubated in the presence of $10^{-4}$ and $10^{-3} \mathrm{M} \mathrm{Mg}^{2+}$, but absent of $\mathrm{Ca}^{2+}$. This indicates that the alternative complement pathway of rainbow trout was activated to some extent by SRBC under these conditions.

\section{DISCUSSION}

Although the assay of the CCP activity of mammals is carried out using SRBC sensitized with rabbit antibody, the complement of fish is incompatible with rabbit antibody. Therefore, the assay of the CCP activity of fishes has been performed using SRBC sensitized with the antibody of homologous fish (Yano et al., 1984 ; Matsuyama et al., 1985 ; Yano et al., 1988) or that of heterologous fish which is compatible with the complement of the test fish (Legler and Evans, 1967 ; Legler et al., 1967). In this experiment, we examined the properties of the CCP of rainbow trout utilizing SRBC sensitized with porgy antibody which is compatible with rainbow trout complement.

The CCP of rainbow trout showed highest activity under following conditions: reaction temperature, $20-25^{\circ} \mathrm{C} ; \mathrm{pH} 7.5$; concentrations of $\mathrm{Ca}^{2+}$ and $\mathrm{Mg}^{2+}, 1 \mathrm{mM}$ and 10 $\mathrm{mM}$, respectively.

In a preliminary study, we observed that rainbow trout serum hemolyzed SRBC to a considerable extent in the presence of $10 \mathrm{mM} \mathrm{Mg}^{2+}$. This hemolysis is attributable to the alternative complement pathway of rainbow trout. However, the hemolysis by the ACP was less than $10 \%$ of the total hemol'ysis when the hemolytic reaction was performed in the presence of $1 \mathrm{mM} \mathrm{Ca}^{2+}$ and $1 \mathrm{mM} \mathrm{Mg}^{2+}$. This indicates that the CCP 
activity of rainbow trout can be assayed under these conditions.

We have shown in the previous paper (Yano et al., 1988) that the titration of the CCP activity (CH50) of carp, porgy and tilapia can be performed under an uniform conditions as follows : reaction temperature, $25^{\circ} \mathrm{C} ; \mathrm{pH}, 7.5$; concentrations of $\mathrm{Ca}^{2+}$ and $\mathrm{Mg}^{2+}, 1.0 \mathrm{mM}$ and $1.0 \mathrm{mM}$, respectively. The present experiment showed that the activity of rainbow trout CCP could also be assayed under the same conditions.

\section{ACKNOWLEDGEMENTS}

We are grateful to $\mathrm{T}$. Uemura for his excellent technical assistance.

\section{REFERENCES}

Legler, D. W. and E. E. Evans 1967 Comparative immunology : Hemolytic complement in elasmobranchs. Proc. Soc. Exp. Biol. Med., 124 : 30-34

Legler, D. W., E. E. Evans and H. K. Dupree 1967 Comparative immunology : Serum complement of fresh water fishes. Trans. Am. Fish. Soc., 96: 237-242

Matsuyama, H., A. Hirata, M. Nakao and T. Yano 1985 Optimum conditions for the assay of hemolytic complement titer of porgy (Pagrus major) serum. J. Fac. Agr., Kyushu Univ., 30 : 149158

Yano, T., H. Ando and M. Nakao 1984 Optimum conditions for the assay of hemolytic complement titer of carp and seasonal variation of the titers. J.Fac.Agr., Kyushu Univ., 29: 91-101

Yano, T., Y. Hatayama, H. Matsuyama and M. Nakao 1988 Optimum conditions for the assay of the classical pathway-complement titer of tilapia (Tilapia nilotica) serum. J.Fac. Agr., Kyushu Univ., 33: 29-36 